\title{
Peran Lingkungan Sekolah dalam Pengembangan Mental Siswa
}

\author{
Edi Kuswadi \\ Sekolah Tinggi Agama Islam YPBWI Surabaya \\ Email: edikuswadi43@gmail.com
}

\begin{abstract}
Abstrak
Artikel ini bertujuan untuk mengkaji seberapa besar peran lingkungan sekolah dalam pengembangan mental peserta didiknya. Asumsi yang beredar adalah adanya keterhubungan erat penuh pengertian antara sekolah, peserta didik, wali serta masyarakat. Penelitian ini secara umum mendapati bahwa secara garis besar peran lingkungan sekolah dalam proses perencanaan, pelaksanaan dan penyediaan informasi yang diperlukan bagi peserta didik sanagt penting. Ia harus mampu memberikan pelbagai alternatif keputusan yang dapat dipergunakan peserta didik guna menjalani hidup dan menyelesaikan seluruh problematik yang dihadapinya. Oleh karena itu, pelaksanaan proses pendidikan mental dan konseling harus diupayakan untuk memperoleh informasi yang diinginkan dari rangkaian program yang telah direncanakan dan dilaksanakan di sekolah. Di sekolah guru mengumpulkan data untuk merekap siswasiswa yang butuh bimbingan. Hal tersebut memudahkan guru bimbingan dalam melaksanakan tugasnya Karena hal tersebut bisa merekap siwa dalam mencapai targetnya.
\end{abstract}

Kata kunci: Pendidikan mental; rapport; sindrom UN; indisiplinasi; konselor.

\section{Pendahuluan}

Sekolah memegang peranan penting bagi perkembangan mental dan emosional bagi siswa-siswinya. Penanaman karakter terhadap anak usia dini dilingkungan sekolah sangat diperlukan dalam perkembangan individu. Selain itu, Sekolah merupakan kelompok kedua dalam misinya yang ikut andil atau turut mengambangkan karakter, potensi dan mental. Seorang anak setelah di lingkungan keluarga, sekolah juga memiliki peran yang besar untuk memberikan dorongan terhadap individu seorang anak agar dapat berkembang secarai baik sesuai porsi setiap umur dan perkembangannya.

Tak lepas dari hal tersebut, fungsi guru yang seharusnya secara sempit hanya menjadi seorang pendidik, maka guru juga harus berfungsi juga sebagai orang tua bagi siswa-siswinya ketika di sekolah. Hal ini bertujuan agar anak tidak kehilangan sosok orang tua yang bisa 
mengarahkan dan mengayomi ketika ia mendapatkan depresi atau stres karena masalah ketika ia berada di lingkungan sekolah. Guru harus terbuka dan lebiih peka terhadap keadaan atau permasalahan yang dialami oleh siswa-siswinya dengan memberi solusi, masukan dan dorongan dengan baik terhadap anak didiknya.

\section{Definisi Kesehatan Mental}

Kesehatan mental adalah suatu kesehatan yang berkaitan dengan aspek mental dan emosional seorang individu. The World Federation For Mental Health 1948 menjelaskan bahwa kesehatan mental sebagai satu keadaan yang mengedepankan nilai dan tujuan perkembangan individu terutama dalam hal emosi, fisik atau intelektual dan tidak berbanding terbalik dalam artian tidak menyeleweng dan tidak mengganggu lingkungan. Artinya ia merupakan kondisi yang memungkinkan perkembangan optimal yang dialami oleh individu secara fisik. ${ }^{1}$

Secara global orang yang mentalnya sehat merupakan seorang individu yang berkembang, berperilaku wajar serta mampu menyesuaikan dengan pelbagai norma yang berjalan pada satu lingkup sosio masyarakat. Seperti halnya organ tubuh, mental juga harus berfungsi secara baik dan normal dalam setiap periode pertumbuhan. Perkembangan mental dan psikis secara normal dan semestinya tidak kalah penting dengan perkembangan tubuh dan fisik. Setiap manusia pasti mempunyai masalah. Tidak ada manusia yang bebas dari permasalahan atau gangguan. Adakalanya ia merasa sedih, bahagia, haru, ketawa maupun sakit hati. Hal-hal semacam ini merupakan sesuatu yang wajar dalam menjalani kehidupan. Jika kita sedang mengalami hal demikian, maka kita akan tidak merasa nyaman dalam beraktivitas. Misalnya, jika seorang sedang gelisah karena akan menghadapi ujian sekolah, maka hal yang dilakukan dalam beraktivitas adalah akan menampakkan muka yang kusut dan lesu. Hal ini jelas berbeda dengan seseorang yang bahagia karena mendapat hasil ujian terbaik, maka yang disebut terakhir ekspresi wajahnya akan berseri-seri dan tersenyum. ${ }^{2}$

Jika ditinjau dari segi tujuan dari diadakannya suatu lembaga pendidikan, maka lembaga tersebut sejatinya merupakan wadah atau tempat untuk mengembangkan potensi dan membantu untuk mewujudkan apa yang dicita-citakan seorang peserta didik. Pendidikan diharapkan dapat mengubah dan membentuk karakter serta watak seorang murid untuk menjadi generasi millennial yang siap tempur secara psikis dan emosial di dunia yang penuh dengan tantangan, baik itu dalam bidang religi, akademik dan sosial-budaya.

${ }^{1}$ Dede Rahmat Hidayat et al., Bimbingan Konseling Kesehatan Mental di Sekolah (Bandung: PT. Remaja Rosda Karya, 2013), 30.

${ }^{2}$ Ibid., 32. 
Pendidikan yang pertama bagi seorang manusia memerankan peran yang sangat vital. Pendidikan ini tercipta dari keluarga dan lingkungan atau biasa disebut sebagai pendidikan sekunder. Hal ini karena sangat berpengaruh terhadap perilaku seorang murid dan akan membentuk sikap dan karakternya kelak. Oleh karena itu, sekolah berperan penting. Ia merupakan lembaga yang membantu proses pendidikan tersebut, utamanya mengenai sesuatu yang berkaitan dengan aspek akademis dan bersifat formal. Sekolah tidak hanya berisi tentang proses pembelajaran yang dijalankan dalam bentuk pertemuan dalam kelas. Lebih dari itu, ia dapat diejahwantahkan dalam bentuk aktivitas di luar kelas, seperti tentang bagaimana interaksi sosial antarteman dan lingkungan yang dapat membantu membentuk karakter seorang peserta didik. Proses ini penting dalam rangkat membentuk satu manusia yang memiliki sikap yang selaras dengan pelbagai peratutan dan norma-norma lain yang berlaku di dalam masyarakat. Tentunya juga harus mampu memunculkan siswa yang berkarakter secara akademis. $^{3}$

Telah dicantumkan dalam Undang-undang nomor 20 tahun 2003 yang berkenaan dengan Sistem Pendidikan Nasional (sisdiknas). Dalam pasal ke-3 disebutkan bahwa tujuan suatu proses pendidikan adalah "untuk berkembangnya potensi peserta didik agar menjadi manusia yang beriman dan bertakwa kepada Tuhan Yang Maha Esa, berakhlak mulia, sehat, berilmu, kreatif, mandiri dan menjadi warga negara yang demokratis serta bertanggung jawab". Dalam hal ini, lembaga yang berperan adalah sekolah. Sekolah sebagai satu dari pelbagai instrumen bimbingan formal sudah seharusnya menghadirkan satu proses pendidikan yang mumpuni guna mengembangkan segala potensi yang ada dalam diri peserta didik dalam proses belajar mengajar. Sebagai suatu lembanga penyelenggara pendidikan, sekolah dituntut dapat berperan serta dalam menanamkan nilai dan normanorma yang berlaku di masyarakat dalam proses pembelajaran yang berlangsung di sekolah selain. Oleh karenanya, selain mengajarkan pelbagai pengetahuan, sudah sewajarnya sekolah dapat menghadirkan pelbagai bekal seperti kedisiplinan, pengayaan bakat keterampilan serta pelbagai kemampuan lain yang diperlukan oleh peserta didik guna menjadi generasi cerdas yang membanggakan negeri. ${ }^{4}$

Selain dalam bidang akademis, sekolah juga perlu menanamkan nilai-nilai religiositas bagi siswa-siswanya. Penanaman ini dapat diimplementasikan dalam bentuk kegiatan seperti: salat dhuhur, salat dhuha

3 Elsi Novarita, "Perilaku Bolos Siswa dan Implikasikasinya terhadap Layanan Bimbingan dan Konseling", Jurnal Konseling dan Pendidikan, vol. 2, no. 2 (2014), 2.

${ }^{4}$ Ibid., 3 .

64 Jurnal El-Banat 
berjama'ah, baca al-Qur'ān sebelum pembelajaran berlangsung, membaca asmaul husna sebelum pulang sekolah, membaca surat-surat pendek atau sebagai syarat untuk bisa ujian akhir sekolah. Penanaman nilai religiositas bagi peserta didik akan menumbuh dan menciptakan generasi yang taat agama. Contoh lain dapat ditemui dalam proses pengembangan skill dan kesehatan mental siswa utamanya ketika akan menghadapi Ujian Nasioanl (UN) seperti kasus SMA 11 di Surabaya. Seorang siswi yang bernama Piptia kelas dua belas di sekolahnya. Kasusnya beberapa waktu lalu dia mengalami ganguan psikis. Hal tersebut tampak pada perilakunya yang sangat murung dan lebih sering diam, gelisah dan susah tidur. Pada akhirnya dia mengatasi masalahnya dengan konsultasi kepada dokter terdekat. Ternyata diagnosa yang muncul adalah terlalu banyak berpikir mengenai cara menghadapi Ujian Nasional (UN). Hal tersebut membuatnya menjadi malas belajar dan mengakibatkan tidak fokus belajar dan selalu merasa tertekan. ${ }^{5}$

Gambaran tersebut menunjukkan gangguan mental yang dialami siswa SMA 11 Surabaya tersebut termasuk jenis ganguan mental yang memasuki kategori wajar dan tidak cukup serius. Kasus serupa banyak dialami oleh siswa yang sedang menghadapi Ujian Nasional. Gejala yang sering kali muncul adalah hadirnya rasa khawatir, cemas dan takut yang berlebihan. Sebagai lembaga pendidikan dalam hal ini sekolah harus mengadakan beberapa program tambahan seperti bimbingan belajar di luar jam sekolah dan "istighosah" rutinan dalam rangka doa bersama. Seorang siswa atau individu terkena gangguan terhadap kesehatan mental maka hal tersebut juga merupakan gangguan terberat. Pada umumnya penyakit mental merupakan gangguan berat yang harus mendatangkan ahli mental atau ahli dalam penanganan psikis seseorang. Jika seseorang mengalami gangguan mental akibat suatu peristiwa dan tidak dapat ia atasi dengan baik, maka kemudian mentalnya akan menjadi lebih rapuh. Hal ini dapat membawa akibat dikemudian hari dan akan menjadi lebih parah tekanan mentalnya. ${ }^{6}$

\section{Empat Tahapan Konseling}

Dalam menyikapi beberapa persoalan psikis, adalah pelbagai tahap yang dapat dilakukan oleh seorang konselor. Pertama, mengembangkan Rapport. Seorang konselor dalam jiwanya harus tertanam sikap perhatian dan tidak acuh terhadap pasien. Konselor dituntut harus bersikap terampil dan tanggap terhadap lingkungan dan keadaan pasien. Keterampilan tersebut harus dimiliki, sebab hal itu merupakan syarat mutlak ada dalam diri seorang konselor. Keterampilan dasar konselor merujuk pada kompetensi-

\footnotetext{
${ }^{5}$ Ibid.

${ }^{6}$ Hidayat et al., Bimbingan Konseling, 33.
} 
kompetensi yang harus dikembangkan. ${ }^{7}$ Di antara keterampilan dasar tersebut adalah: (1) kompetensi intelektual. Konselor dituntut untuk memiliki pola pikir sistematis, objektif, menempatkan peristiwa pada ranah yang tepat dan objektif. (2) seorang konselor harus lincah dan dituntut untuk fleksibel dalam mnejalankan profesinya. Seorang konselor harus dapat secara luwes menyikapi pelbagai persoalan dan perubahan sikap pasiennya. Tidak hanya itu ia juga dituntut mampu membaca adanya tanda-tanda terjadinya pergeseran ekspektasi dan persepsi dari konseli yang dihadapinya. Secara khusus hal ini harus dihadapi dengan intensionalitas yang baik. Ini perlu karena sangat berhubungan dengan kapasistas seorang konselor dalam menghadapi konseli yang memerlukan bantuannya. Oleh karena itu, konselor harus cepat tanggap terhadap segala apa yang diungkapkan konseli dan meresponsnya dengan cekatan dan tepat. (3) pengembangan keakraban (rapport). Seorang konselor dituntut mampu membangun hubungan baik yang didasari pada sebuah ketulusan, kenyamanan dan kepedulian pemantapan pemeliharaan keakraban selama konseling, keakraban dan semua itu harus dilakukan berdasarkan sikap peduli yang tidak mengesampingkan hubungan yang terbentuk dari interaksi dengan pasien yang berlangsung secara tenang, selaras hangat santai dan saling bertukar gagasan dengan penuh penghormatan terhadap pendapat satu sama lain. ${ }^{8}$

Konselor harus tanggap dalam mencermati keadaan sekitar. Tugas konselor adalah memperbaiki masalah dan memberikan solusi terbaik bagi konseli. Konselor di sekolah adalah guru bimbingan konseling yang harus memantau keadaan siswa-siswa di sekolah dan berperan dalam memajukan atau member wadah untuk potensi-potensi siswanya. Selain itu, tugas konselor atau guru bimbingan konseling bervariasi, kompleks atau tidaknya tergantung kebutuhan sekolah. Di antara tugas konselor: (1) memberikan sesi konseling kelompok individu. Biasanya siswa akan dipanggil per kelompok untuk mendiskusikan hal atau sesuatu yang hendak dicapai. (2) melakukan konsultasi bimbingan kelas. yang mana ini bersifat sebagai penyuluhan kepada semua siswa tidak hanya kelompok tertentu. (3) melakukan konsultasi dengan orang tua, guru, administrator dan perwakilan masyarakat. (4) memberikan advokasi atau perlindungan untuk semua siswa untuk meningkatkan pengalaman pendidikan. (5) menjadi anggota kepemimpinan sekolah dan kelompok pembuatan kebijakan. Biasanya ini sudah menuju babak akhir sebuah konseling dan menuju babak keputusan. (6) menjadi ahli perkembangan dilingkungan sekolah. Menjadi spesialis

\footnotetext{
${ }^{7}$ Muhammad Rozikan, "Spiritualitas Peran Konselor dalam Meningkatkan Kualitas Pelayanan Bimbingan Konseling", Prosiding Seminar Bimbingan dan Konseling, vol. 1, no. 1 (2017), 3.

${ }^{8}$ Ibid., 4.
}

66 Jurnal El-Banat 
kesehatan mental dilingkungan sekolah. Konselor harus menjadi pemantau dan menjadikan karakter siswa menjadi lebih baik. ${ }^{9}$

Selain itu seorang konselor harus mampu mengkoordinasikan program sekolah, termasuk program mediasi, resolusi konflik, pencegahan kekerasan dan pendidikan karakter, mencegah bunuh diri, kehamilan, putus sekolah, penggunaan narkoba dan kerusakan moral lainnya. Menjaga tingkat keahlian yang diperlukan dalam semua bidang di atas untuk memastikan kualitas di semua intervensi dan program. ${ }^{10}$

Implementasi proses konseling atau bimbingan seorang konselor di lingkup sekolah harus memperhatikan beberapa rambu-rambu. Menurut Hidayat beberapa hal yang harus diperhatikan dalam hal ini mencakup asas kesukarelaan, terbuka, kerahasiaan, mandiri, kekinian, kegiatan, keterpaduan, kedinamisan. Selain itu ada beberapa asas lain yang tidak kalah penting, seperti asas normativitas, keahlian, keterpaduan, alih kasus dan asas "tut wuri handayani". Seorang peserta didik dalam hal ini sebagai seorang konseli harus mampu dipahamkan tentang tugas-tugas yang harus ia emban. Kewajiban-kewajiban tersebut sangat terkait dengan nilai-nilai religiositas, kedamaian, makna serta tujuan hidup dan kemampuan dalam mengambil suatu keputusan penting dalam hidup. Hal-hal tersebut harus dihadirkan dalam bentuk pelbagai aktivitas yang berkaitan dengan pertahanan, pengendalian diri, motivasi hidup realistis, memiliki tingkat kesadaran emosional yang baik dan dapat menyesuaikan diri. Selain itu, peserta didik harus mempunyai pelbagai sikap mental yang kreatif, humoris, rajin dan memiliki kemampuan menyelesaikan segala persoalan yang dihadapi. ${ }^{11}$

Kedua, identifikasi masalah. Pelayanan dan bimbingan dalam satu rangkaian proses konseling harus memiliki orientasi ke depan dan berkembang. Maksudnya proses konseling harus mampu menghadirkan satu bimbingan dan pelayanan yang memadai serta mengedepankan satu bentuk pelayanan yang dapat memacu seorang peserta didik untuk dapat "tercerahkan" dalam menghadapi pelbagai persoalan dengan memanfaatkan potensi yang inheren dalam diri mereka. Seorang konselor dalam hal ini guru bimbingan konseling dituntut untuk menjadi wadah bagi para siswanya untuk membantu mewujudkan apa yang diharapkan oleh siswa kedepannya. Permasalah siswa juga tidak ketinggalan yang harus di ketahui oleh guru bimbingan konseling karena guru bimbingan konseling ini sifatnya menjadi

\footnotetext{
${ }^{9}$ Ibid.

${ }^{10}$ Dini Rakhmawati, “Konselor Sekolah Abad 21: Tantangan dan Peluang”, Jurnal Konseling Gusjigang, vol. 3, no. 1 (2017), 61.

${ }^{11}$ Hidayat et al., Bimbingan Konseling, 89.
} 
orang tua kedua setelah ayah ibu mereka. Guru bimbingan konseling harus lebih terbuka dan membuat siswa merasa nyaman ketika berkonsultasi. ${ }^{12}$

Dalam perspektif Sofyan Willis menemukakan dalam proses pendidikan yang menggunakan kegiatan bimbingan konseling terdapat beberapa tujuan yang ingin dicapai. (1) pengembangan potensi, kreatifitas, kemandirian, religiositas dan produktifitas peserta didik secara optimal. (2) menghadirkan solusi yang tepat, cepat serta relevan bagi seluruh persoalan yang dihadapi, utamanya yang menyebabkan adanya ketertekanan emosional (stress). Keduanya dihadapkan dapat tercapai demi menghasilkan kemampuan perserta didik dalam merencanakan masa depannya dengan baik dan tahan banting. ${ }^{13}$

Menurut Dewa Ketut Sukardi, bimbingan dan konseling sejarinya merupakan proses menghadirkan pelbagai pertolongan kepada konseli yang memerlukan bantuan. Bantuan ini diberikan utamanya sebagai bentuk suportif bagi peserta didik dalam menemukan konsep dan kepercayaan diri. Keduanya diperlukan sebagai bekal dalam memperbaiki segala persoalan utamanya yang berkaitan dengan sikap dan tingkah lakunya di masa mendatang. Sesuai dengan peran guru Bimbingan Konseling (BK) di sekolah yang menjadi pemantau atau penanggung jawab perilaku siswa-siswinya di sekolah, maka guru bimbingan konseling harus melakukan pelayanan atau penyuluhan kepada siswa yang melanggar peraturan sekolah agar kembali dan lebih disiplin sebagaimana mestinya. ${ }^{14}$

Berikut macam-macam pelayanan bimbingan konseling yang diterapkan di sekolah seperti layanan informasi. Layanan informasi sangat penting dalam pelayanan bimbingan dan konseling. Layanan ini berfungsi memberikan informasi yang dibutuhkan oleh siswa. Menurut Prayitno dan Erman Amti mengemukanakan tentang layanan informasi yaitu bertujuan dengan memberikan informasi yang diperlukan peserta didik yang memerlukan bantuan guna menyelesaikan persoalannya. Pelayanan informasi yang diberikan oleh guru bimbingan konseling di sekolah bisa dengan topik akibat bolos sekolah. Dalam pemberian topik ini, guru bimbingan konseling harus bisa memberikan informasi dengan tutur kata yang baik, sistematis dan mudah ditangkap oleh peserta didik serta cara penyampaiannya pun harus menarik perhatian siswa dan tidak monoton. Ini harus dipenuhi sehingga siswa tidak merasa bosan dan jenuh ketika guru menyampaikan penyuluhan. Harapan di sini siswa bisa lebih senang dan

12 Paul Arjanto, "Identifikasi Masalah Menggunakan Teknik ProblemCheck-List Pada Mahasiswa Program Studi Bimbingan dan Konseling Universitas Pattimura", Jurnal Konseling Indonesia, vol. 1, no. 1 (2015), 11.

${ }^{13}$ Ibid.

${ }^{14}$ Novarita, "Perilaku Bolos Siswa", 12. 
lebih termotivasi untuk melakukan kegiatan dan menerapkan apa yang disampaikan oleh para konselor. ${ }^{15}$

Oleh karena itu, tidak mengherankan kalau Prayit menilai bahwa proses bimbingan konseling sejatinya merupakan pelayanan konsultasi dan penyelesaian masalah yang dilakukan oleh seorang konselor terhadap seorang konseli guna menyelesaikan persoalan yang dihadapinya. Penerapan layanan ini dapat dilakukan secara perorangan (individu) dengan perantara guru BK. Guru tersebut sudah seharusnya memberikan bantuan berupa penyuluhan kepada siswa yang sedang melaksanakan konseling perorangan secara langsung berupa arahan dan meyakinkan siswa bahwa perilaku bolos sekolah yang dilakukan siswa itu salah dan periaku bolos bisa berdampak terhadap kelangsungan belajarnya. ${ }^{16}$

Sulit menggambarkan untuk memberi patokan batas kenormalan terhadap kepribadian seseorang. Ada beberapa pendapat ahli dalam menggambarkan jenis-jenis kepribadian yang dapat menimbulkan kepribadian sosial. Adapun upaya dalam menggambarkan manusia memiliki kesehatan mental yang baik yaitu: bebas dari gejala-gejala (sintom-sintom). Sebagai kriteria pertama tentang kepribadian normal dapat dikemukakan ungkapan sikap dan sifat seseorang yang dilakukan dengan bahasa tubuh atau isyarat. Misalnya ada kecemasan mata menolak melihat sesuatu yang kurang menyenangkan atau tidak indah jika dilihat. Terkadag juga ada orang-orang yang tuli terhadap hal-hal yang tidak disenanginya untuk diperdengarkan. Walaupun alat pendengarannya tidak rusak. maksud dari tuli di sini adalah mereka tidak cacat secara fisik tetapi tidak peduli atau tidak ingin mendengar. Ada juga pasien yang sakit perut akibat keadaan atau kondisi hidupnya yang tidak menyenangkan dan tidak memuaskan terhadap dirinya. ${ }^{17}$

Selain itu juga tidak ada hambatan yang disebabkan oleh konflik mental. Setiap orang pernah menghadapi konflik mental yang harus dihadapinnya. Seseorang yang penyesuaian atau adaptasinya baik dapat menghadapi masalah atau gangguan yang terjadi pada dirinya secara ringan dan tidak berlarut-larut dalam kesedihan. Ia akan mempunyai kesanggupan bekerja dengan memuaskan. Memiliki kesanggupan bekerja yang memuaskan merupakan syarat penting bagi terciptanya suatu kepribadian dengan kemampuan yang baik. Terakhir adalah mencintai orang lain ketimbang dirinya sendiri. Secara simpel hal ini dapat dijelaskan sebagai suatu pemecahan segala persoalan dengan baik. Ciri khas dari suatu

\footnotetext{
15 Ibid.

16 Ibid., 13.

17 Yulia Singgi D. Gunarsa, Asas-Asas Psikologi Keluarga Idaman (Jakarta: Gunung Mulia. 2012), 109.
} 
persoalan di antaranya: selalu hadir sebagai akibat dari kesenjangan antara cita-cita yang diharapkan dan realita yang dihadapi; dampak dari sikap dan perbuatan yang tidak disukai oleh diri sendiri maupun masyarakat; dan persoalan hadir sebagai dampak dari proses pendidikan yang salah. Secara umum semakin jauh bentuk kesenjangan tersebut maka persoalan yang muncul akan semakin kompleks dan berat. Setiap gap yang ada pasti akan memunculkan pelbagai cara pandang yang bervariasi dalam menyikapinya. ${ }^{18}$

Tidak dapat dipungkiri para peserta didik sering kali mengalami gangguan mental. Di antara beberapa permasalahan tersebut di antaranya: Pertama, masalah belajar. Belajar sejatinya merupakan proses yang dilalui oleh peserta didik guna mendapatkan satu rangkaian perilaku baru yang dapat berperan dalam kehidupannya secara menyeluruh. Ia merupakan produk yang dihasilkan dari pelbagai pengalaman yang dilalui dan akan dipergunakan dalam rangkaian interaksi dengan lingkungan secara luas. Pengalaman ini dapat diperoleh dari keluarga yang menjadi madrasah pertama maupun masyarakat, teman sebaya dan dari pendidikan formal yang berlangsung di sekolah. ${ }^{19}$

Kedua, masalah emosi. Selain masalah yang berhubungan atau yang terkait dengan belajar, ada juga persoalan siswa yang perlu diperhatikan oleh para guru yaitu persoalan yang berkenaan dengan emosi. Emosi dapat kita klasifikasikan ke dalam dua hal: sensoris dan psikis. Tipe pertama merupakan satu keadaan yang muncul karena ada stimulus dari faktor eksternal individu. Stimulus ini dapat berupa rasa yang ditangkap panca indra maupun perasaan, seperti rasa sakit, mengantuk, kenyang, panas dan beberapa lainnya. Tipe kedua, psikis, lebih merupakan satu emosi yang terbentuk dari pelbagai sebab yang melatarbelakanginya. Sebab-sebab ini umumnya berupa persoalan yang berkenaan dengan dimensi kejiwaan, seperti: perasaan tentang kebenaran ataupun rasa terhadap orang lain, keluarga maupun lawan jenis. Dalam skala yang lebih luas tipe kedua sangat ditentukan oleh ada tidaknya relasi satu individu dengan individu maupun kelompok lain. Oleh karena itu, tipe ini lebih menekankan pada pentingnya satu etika, estetika kemanusiaan dan yang berkaitan dengan keberagamaan. ${ }^{20}$

Emosi sangat mungkin diartikan sebagai satu sarana mengkomunikasikan perasaan yang terpendam di dalam diri. Anak akan lebih cenderung melakukan apa yang menjadi keinginan internal dalam dirinaya melalui suatu tindakan yang disebut emosi. Biasanya ia menunjukkan suatu perasaan yang menjadi kebutuhan dan keinginannya. Misalnya seorang anak akan tersenyum menandakan sesuatu yang

\footnotetext{
${ }^{18}$ Arjanto, "Identifikasi Masalah", 12.

19 Ibid., 12.

${ }^{20}$ Ibid.
} 
menyenangkan dirinya. Ia akan menangis jika persaan atau keinginannya tidak segera diwujudkan oleh orang tuanya, karena emosi anak tidak bisa ditahan oleh dirinya ia cenderung langsung mengekspresikan dari pada menahan seperti halnya orang yang sudah dewasa. Emosi sangat memungkinkan untuk dinyatakan sebagai barometer status sosial seseorang. Misalnya, seorang anak menangis menandakan minta perhatian terhadap orang tuanya. ${ }^{21}$ Ini mengidentifikasikan bahwa emosi ada dan memerankan satu hal yang sangat penting. Ia adalah cerminan keadaan jiwa seseorang.

Di antara pengaruh-pengaruh emosi yang sering terjadi adalah yang berkaitan dengan adaptasi individual maupun sosial. Hal ini setidaknya akan memunculkan beberapa dampak, seperti: pertama, hadinya emosi akan menstimulus hati untuk lebih senang ataupun sebaliknya dalam kehidupan sehari-hari seorang manusia. Saat marah emosi yang mendominasi adalah rasa marah, begitu juga saat senang akan memunculkan emosi positif yang dapat menambah stimulus secara aktif terhadapnya. Misalnya, ada seorang anak marah karena berharap dengan marahnya lingkungan di mana ia berada dapat menjadi sesuai dengan harapannya. Emosi yang ada dalam diri anak tersebut secara tidak langsung akan mendorongnya untuk melakukan satu tindakan tertentu secara intens. Oleh karena itu, perlu ada satu keseimbangan dalam emosi, sehingga dapat menuntun sikap atau perilaku yang baik. Kedua, rendahnya emosi dalam diri akan berpengaruh terhadap kemampuan motorik satu individu. Hal ini kemudian akan memicu kesiapan fisik dalam beraktivitas akan semakin sulit, sehingga memunculkan perasaan cangkung atau bahkan terkesan kaku dan akhirnya akan mengganggu gangguan kemampuan linguistik, seperti cara berbicara yang gagap. Ketiga, emosi sebagai bentuk komunikasi. Emosi muncul dalam melalui raut wajah dan gerakan tubuh. ${ }^{22}$

Berkaitan dengan ini Surya menjelaskan beberapa bentuk gejala gangguan mental di sekolah sebagai berikut: Pertama, masalah kesulitan belajar. Belajar adalah hal yang terpenting yang harus terfokuskan bagi para siswa. Jika dilihat dari sisi kendala pembelajaran maka salah satu sebab dari kesulitan belajar adalah adanya gangguan mentalitas yang dikarenakan pelbagai sebab. Disebut salah satu sisi karena ada hal lain yang sangat mungkin untuk menjadi sebab atas kendala yang dihadapi dalam proses pembelajaran. Artinya, sebagai suatu kendala pembelajaran, kesehatan mental sejatinya merupakan kondisi yang dimunculkan oleh adanya pertentangan ataupun konflik yang terjadi dalam diri (batin) peserta didik. ${ }^{23}$

\footnotetext{
${ }^{21}$ Gunarsa, Asas-Asas, 58.

${ }^{22}$ Ibid., 59.

${ }^{23}$ Ngalim Purwanto, Prinsip-Prinsip dan Teknik Evaluasi Pengajaran (Bandung: Remaja Rosdakarya, 2001), 3.
} 
Kedua, masalah kenakalan remaja. Persoalan kenakalan remaja sering kali terjadi di kota-kota besar, walaupun tidak menutup kemungkinan terjadi di desa-desa terpencil. ${ }^{24}$ Permasalahan ini tidak bisa dipisahkan begitu saja dari peran serta sekolah sebagai lembaga pendidikan metal dan intelektualitas peserta didik. Kenakalan terindikasi muncul sebagai bentuk kurangnya rasa tanggung jawab dalam diri individu. Hal ini tampak dalam pelbagai aktivitas mereka, terutama yang berkaitan dengan tingkah laku, seperti: seperti sifat agresif yang berlebihan, terjadinya perkelahian sesama siswa, pembentukan geng, membuat coretan-coretan yang tidak senonoh ataupun merusak fasilitas sekolah. Siswa yang mengalami beberapa hal tersebut, sejatinya dapat digolongkan sebagai anak dengan gangguan kesehatan mental.

Beberapa persoalan yang sering dijumpai dalam diri individu mencakup beberapa hal. Di antaranya: pertama masalah disiplin. Mentalitas anak yang sehat akan menunjukkan kecenderungan untuk memperhatikan atau bertindak disiplin dan menaati pelbagai aturan yang berlaku di sekolah dan masyarakat. Terjadinya pelanggaran disiplin dengan siswa sebagai aktornya menunjukkan adanya persoalan dalam diri peserta didik tersebut. Adanya pelbagai indisiplinasi siswa seperti hadir di sekolah terlambat, sering mengambil hak milik orang lain, suka menyontek tidak semata-mata disebabkan ketiadaan pengetahuan mereka akan informasi tentang disiplin yang berlaku, namun sering kali terjadi akibat ketidak seimbangan mentalnya. Dalam beberapa kasus yang terjadi, kenakalan siswa menunjukkan adanya gangguan mentalitas dalam batinnya. Beberapa yang paling sering ditemui adalah rasa takut atau cemas yang berlebihan, maupun merasa tertekan karena satu hal. Dampaknya mereka sering bertingkah pesimis, mudah tersinggung, murung, dingin bahkan bersikap histeris maupun sampai mengkonsumsi obat-obatan terlarang. ${ }^{25}$

Salah satu persoalan yang paling berkaitan dengan mentalitas seorang peserta didik muncul di waktu mendekati ujian nasional (UN). Oleh karena itu, UN menjelma menjadi satu sindrom tersendiri. Di antara beberapa persoalan yang sering kali muncul di masa UN adalah rasa stres, gelisah, panik, tegang, takut dan khawatir dalam menjalani ujian tersebut. Secara psikologis rangkaian proses ujian sering kali memicu terjadinya tekanan yang luar biasa besar dalam psikologis siswa, bahkan hal ini kerap mendominasi pikiran peserta didik yang menghadapinya, meskipun tidak jarang pula ditemukan peserta didik yang tidak banyak terpengaruh dengan persoalan tersebut. Sindrom ujian ini perlu direspons dengan tepat, cermat

\footnotetext{
${ }^{24}$ Hidayat et al., Bimbingan Konseling, 95.

${ }^{25}$ Ibid., 96-104.
} 
dan lengkap. Penanggulangan persoalan tersebut memerlukan kerjasama yang terpadu antara murid, guru, sekolah, keluarga dan masyarakat. Dalam situasi ujian sindrom semacam ini kerap menimbulkan gangguan kesehatan fisik, meskipun sejatinya ia lahir sebagai dampak ketidaksiapan mental. Ada beberapa anak yang mudah lemas, lesu, cemas bahkan sakit fisiknya selama menjalani ujian tersebut. Upaya untuk menanggulangi sindrom ini membutuhkan persiapan dan support secara menyeluruh, dari aspek moral, intelektual, spiritual, psikologis, emosional dan material dari seluruh pihak yang terlibat. ${ }^{26}$

Istilah ujian nasional (UN) seolah-olah menjadi nama yang menyeramkan bagi para siswa kelas akhir, gejolak mental begitu mencekam terjadi perubahan perilaku berupa gangguan kesehatan mental bagi yang tidak lulus. Mulai dari yang ringan misalnya dengan menangis, disteris dan histeris yang berat berupa pingsan, bunuh diri, sampai tindakan anarkis berupa bentuk perusakan fasilitas sekolah yang sebenarnya sangat mereka cintai dan seharusnya menjadi sebuah kenangan atau ukiran di sana. Kementrian pendidikan nasional RI segera membuka posko penanggulangan trauma stres yang dibangun di setiap perguruan tinggi negeri bagi peserta UN yang mengalami gangguan hebat akibat tekanan UN. Posko itu terutama didirikan di beberapa universitas di luar pulau Jawa, seperti pulau Kalimantan, Sulawesi, Sumatra dan Nusa Tenggara Timur. Di setiap posko tersebut disiapkan psikolog yang siap siaga dan akan membantu siswa peserta ujian nasional (UN) yang sedang mengalami gangguan mental atau psikisnya. ${ }^{27}$

Beberapa gangguan yang harus di himbau oleh orang tua dan guru terhadap mental anak adalah Gangguan Kecemasan. Siswa-siswa dengan gangguan kecemasan biasanya mengalami gangguan suatu keadaan yang penuh akan rasa was-was, takut, tertekan ataupun penuh ancaman. Hal ini diperparah dengan munculnya tanda-tanda tertentu dalam fisiknya, seperti gemetaran, gugup, berkeringat maupun meningkatnya detak jantung. Selain itu gangguan dalam berperilaku juga ikut mengganggu. Peserta didik yang mengalami kendala seperti cenderung menolak dan melanggar segala macam peraturan dan hal-hal lain yang mengikat utamanya yang ada di lingkungan atau fasilitas sekolah. Ada juga persoalan lain yang berkaitan dengan daya pervasif. Biasanya siswa yang mengalami ganguan ini mengalami kebingungan dalam pola pikir dan umumnya mengalami satu persoalan yang berkaitan dengan kemampuan dalam membaca lingkuangan sekitar. ${ }^{28}$

\footnotetext{
${ }^{26}$ Ibid., 104.

${ }^{27}$ Ibid., 105.

${ }^{28}$ Ibid.
} 
Selain itu ada pula persoalan yang berkaitan dengan gangguan makan. Hal ini sering kali terjadi sebagai dampak mental atau emosi yang terganggu. Gangguan ini juga melibatkan sikap, ucapan dan perbuatan yang tidak wajar yang berhubungan dngan berat badan ataupun makanan. Ada juga gangguan eliminasi. Gangguan eliminasi merupakan gangguan yang mempengaruhi perilaku yang berhubungan dengan kamar mandi. Kemudian gangguan belajar dan komunikasi. Anak-anak dengan gangguan ini memiliki masalah penyimpanan dan pengolahan informasi, serta yang berhubungan dengan pikiran dan ide mereka. Terakhir adalah gangguan afektif (suasana hati). Jenis gangguan ini melibatkan perasaan kesedihan persistem atau suasan hati yang cepat berubah, serta termasuk depresi dan gangguan bipolar. $^{29}$

Gangguan-gangguan seperti di atas tentu ada faktor-faktor penyebabnya, seperti: pertama, keturunan (genetik). Gen merupakan unit bilogis dasar dereditas yang berisi intruksi untuk fungsi dari setiap sel dalam tubuh. Maksud gangguan genetik adalah suatu bentuk gangguan mental yang berada pada sebuah keluarga. Hal ini menunjukkan bahwa sebuah ganguan mungkin bisa jadi karena wariskan dari kedua orang tua kepada keturunan mereka melalui faktor genetik.. Kedua, biologis. Sebagian kondisi mental seseorang ada yang berkaitan dengan kondisi kimiawi dalam dirinya, khsusus yang telah mengalami perubahan melalui proses neurotransmitter. Neurotransmitter sendiri sejati merupakan usaha dalam memacu rangkaian sel-sel saraf di otak untuk dapat berkomunikasi secara intens. Jika tingkat kimiawi dalam diri mengalami ketidak seimbangan ataupun mengalami gangguan, maka proses komunikasi antarsel dalam diri pastinya akan mengalami gangguan yang sangat mungkin tidak tersampaikan ke otak dengan baik dan selanjutnya memicu respons yang salah.

Keempat, trauma psikologis. Beberapa gangguan mental mungkin terpicu salah satunya oleh trauma psikologis, seperti penyalahgunaan emosional, fisik, atau seksual, kerugian awal yang penting, seperti kehilangan orang tua dan penelantaran. Kelima, stres lingkungan. Peristiwa stres atau tarumatik dapat memicu gangguan pada seesorang dengan kerentaran terhadap gangguan mental. ${ }^{30}$

Peran konselor di sini sangat penting terhadap konseli. Di antara peran tersebut adalah: konselor harus mampu menjadi fasilitator perubahan. Dalam proses pengembangan diri peserta didik sudah sewajarnya harus diawali dengan proses perancangan program guna mengoptimalisasi segala potensi yang ada dalam dirinya. Potensi-potensi tersebut setidaknya

\footnotetext{
${ }^{29}$ Ibid., 106.

${ }^{30}$ Ibid., 108.
}

74 Jurnal El-Banat 
mencakup tiga hal, yaitu: peserta didik, orang tua dan guru di sekolah. Tugas seorang konselor yang pertama adalah dapat menangkap dan menerjemahkan dari suatu proses perubahan yang terjadi. Konselor sudah seharusnya mampu mengidentifikasi pelbagai tandangan dan potensi yang ada dalam lingkungan baik itu sekolah, rumah maupun masyarakat secara luas. Terlebih lagi ia harus mampu mampu menganalisis segala hal yang memungkinkan seorang peserta didik untuk dapat mendapat kesempatan guna menjelma menjadi suatu keuntungan di suatu ketika nanti. Hasil proses analisis ini harus dituangkan ke dalam satu produk yang dapat memacu perkembangan diri peserta didik. Seluruh konselor harus mampu mengakomodasi segala potensi yang bersemayam dalam diri murid, guru dan orang tua serta harus mampu mengemasnya menjadi satu bentuk bimbingan konseling yang dapat mendorong perkembangan kompetensi peserta didik sesuai bakat, minat dan kapasitasnya. ${ }^{31}$

Selain itu, advokasi untuk diri mereka sendiri dan program mereka, melaksanakan program secara komprehensif yang sudah dirancanng dengan baik, berkolaborasi dengan pihak lain, personil sekolahdan dengan lembagalembaga dan program masyarakat, memfasilitasi siswa baik kebutuhan maupun program prestasi, membuat komunitas yang nyaman di ruang lingkup sekolah, menjaga profesinalisme. ${ }^{32}$ Sekolah beserta sistemnya terdiri dari sejumlah besar profesional dan sukarelawanyang menyediakan layanan yang tak terbatas bagi siswa orang tua dan guru yang membutuhkan. Program sekolah berinteraksi secara langsung maupun tidak langsung dengan kolompok. Memang hal ini bukan merupakan pencapain yang mudah. Tuntutan waktu yang sering menghambat. Karena peran konselor adalah untuk menyediakan layanan langsung ketika di sekolah. Pada waktu yang bersamaan, konselor harus mempelajari orang tua dan wali siswa di sekolah. Seperti yang telah dijelaskan sebelumnya, kolaborasi dengan orang tua dan wali memiliki dampak signifikan terhadap layanan konseling langsung dengan siswa. ${ }^{33}$

Orang yang pertama harus memantau adalah orang tua dan wali adalah konselor. Keterlibatan orang tua sangat kuat pada tahun-tahun sekolah dasar, lalu berkurang ketika siswa memasuki tingat yang lebih tinggi. Namun orang tua juga menjadi faktor penting ketika anak memasuki masa remaja. Perubahan dari keterlibatan orang tua dalam keterlibatan dan perkembangan anak terutama dalam mengambil keputusan. Hasilnya adalah bahwa sekolah, guru dan konselor harus membentuk hubungan kerjasama dengan orang tua dan wali dalam merancang program-program pendidikan

\footnotetext{
${ }^{31}$ Rozikan, "Spiritualitas Peran Konselor", 4.

${ }^{32}$ Rakhmawati, "Konselor Sekolah", 61.

${ }^{33}$ Hidayat et al., Bimbingan Konseling, 142.
}

El-Banat Vol. 9. No.1, Januari-Juni 201975 
bagi siswa. Layanan langsung yang disediakan konselor untuk orang tua adalah program-program pendidikan. menjadi orang tua adalah peran menantang yang jarang sekali dipersiapkan di dunia formal. Keterampilan menjadi orang tua merupakan hal yang kita pelajari, kita adopsi dari yang kita lihat, apa yang dilakukan oleh orang tua dan wali ketika itu. Kolompok dukungan bagi orang tua biasanya terfokuskan pada menjadi orang tua tunggal dan konselor memimpin kelompok ini dalam diskusi masalah umum dan eksplorasi tindakan untuk menangani masalah sehari-hari. ${ }^{34}$

Selain orang tua konselor yang berfokus pada kebutuhan informasi dan pendidikan orang tua, memastikan bahwa sekolah dan orang tua bergerak dalam arah yang sama dan memiliki tujuan yang serupa untuk siswa. Untuk memastikan pergerakan pararel ini konselor juga melakukan konsultasi dan kolaborasi dengan guru di sekolah demi terwujudnya suatu visi yang sama terhadap suatu masalah yang diamali oleh anak didiknya. Guru adalah salah satu tanda awal kolaborasi antara konselor dan guru adalah masukan yang diminta oleh konselor mengenai ruanglingkup dan terfokus program konseling di sekolah. Konselor yang meminta hal ini diterima dan dihargai dengan baik, karena mereka menunjukkan penghargaan alamiah mengenai hal apa yang sepatutnya dikerjakan guna menjadi seorang guru yang baik. Konselor melakukan kerjasama dengan guru melalui banyak cara. Misalnya: guru dan konselor saling melakukan konsultasi untuk mengidentifikasi kebutuhan siswa atau anak didiknya secara individu, mengumpulkan data untuk menilai kebutuhan inti, membuat keputusan mengenai strategi praktis untuk membantu siwa dan menilai hasil stategi tersebut. ${ }^{35}$

Tidak kalah penting dengan orang tua dan guru, peran kepala sekolah juga memiliki wewenang dan memberi keputusan terbaik terhadap permasalahan anak didiknya. Kepala sekolah memiliki pengetahuan kebijakan lokal batasan finansial dan batasan yang lain yang membimbing pemilihan dan implementasi aktivitas yang direncanakan untuk sekolah. Dengan cara memngembangkan hubungan dengan kepala sekolah, konselor lebih baik memiliki informasi mengenai paramenter fungsi program layanan mereka. Di samping itu komunikasi yang efektif dengan administrator dengan membuka kesempatan bagi konselor untuk melaksanakan penilaian siswa dan seluruh iklim sekolah, serta bagaimana kedua elemen ini saling berinteraksi di sekolah. ${ }^{36}$

Ummu Kultsum mengutip pendapat Hurlock tentang peran penting sekolah usahanya memacu perkembangan individu siswa. Menurutnya faktor

\footnotetext{
${ }^{34}$ Ibid., 145 .

${ }^{35}$ Ibid., 147.

${ }^{36}$ Ibid., 150.
}

76 Jurnal El-Banat 
penentu utama dalam diri peserta didik baik yang berkaitan dengan intelektualitas, bertindak ataupun berperilaku berlaku adalah mentalitas (emosi). Sekolah memainkan perannya sebagai pengganti keluarga. Di sekolah guru adalah perwujudan dari orang tua. Selain itu, sekolah juga dinilai berperan dan bertanggungjawab dalam proses konseling siswa demi mencapai tujuan yang diharapkannya. ${ }^{37}$ Berkaitan dengan hal ini, sekolah selayaknya berusaha menghadirkan iklim dan kondisi kondusif demi menjadi fasilitator bagi peserta didik guna mempersiapkan diri dalam proses perkembangan dalam hidup. Ada juga Yusuf yang mengatakan bahwa kesehatan mental individu dipegaruhi oleh kualitas iklim sosio-emosional di sekolah. Apabila iklim tersebut kurang kondusif, maka perkembangan kesehatan mental individu akan mengalami kegagalan atau hambatan. ${ }^{38}$

Terlepas dari itu semua, sudah sewajarnya bagi sekolah dan guru harus bersikap bijak dan penyayang kepada siswanya karena siswa dalam berkonseling tidak patut diberi perilaku yang tegas tetapi lebih condok kepada kelesan dan kenyamanan. Hal tersebut yang membedakan pakan siswa harus dibimbing dan kapan siswa harus dihukum. Hal-hal semaam ini sangat berkaitan dengan unsur-unsur kematangan berinteraksi dalam sosiomasyarakat, personal, dan mampu mencapai makna filosofis dalam hidup serta mendorong tingkat keimanan dan ketakwaan Tuhan. ${ }^{39}$

\section{Penutup}

Kesehatan mental sejatinya merupakan keadaan yang sangat berpengaruh terhadap tingkat optimalisasi perkembangan seorang peserta didik. Perkembangan ini sangat berkatian dengan pelbagai aspek yang berkenaan dengan siswa tersebut, seperti fisik, psikis, intelektualitas maupun tingkat kondisi emos siswa selama tidak bertolakbelakang dengan lingkungan dan masyarakat luas. Seseorang yang mengalami ganggan mental maka perkembangan organ dalam tubuh tidak bekerja dengan baik, akibatnya ia akan merasa murung, cemas dan tidak melakukan kegiatan secara fokus.

Di sini sekolah berfungsi untuk menjadi wadah dan sarana bagi siswa dalam pengembangan mentalnya, memenuhi kebutuhan dan pelayanan siswa untuk terus maju dalam belajar dan mengembangkan potensinya agar terciptanya generasi-generasi yang membanggakan negeri. Siswa yang mengalami gangguan mental tidak bisa melakukan hal-hal yang sesuai harapan keluarga, guru maupun masyarakat secara luas. Oleh karenamnya, peran guru bimbingan konseling adalah untuk memperbaiki dan mengawasi

37 Ummu Kultsum, "Pengaruh Implementasi Bimbingan dan Konseling terhadap Perilaku Delinkuen pada Peserta Didik”, Auladuna, vol. 2, no. 1 (2015), 4.

${ }^{38}$ Hidayat et al., Bimbingan Konseling, 97.

${ }^{39}$ Ibid. 
keadaan mental setiap siswanya terutama dalam masa-masa yang sulit seperti ketika akan menghadapi ujian nasional. Dalam menjalin tahap-tahap bimbingan konseling, ada empat proses yang harus dilalui oleh seorang konselor, di antaranya: menjalin keakraban (pengembangan raport), mengidentifikasi masalah yang dihadapi oleh klien, menyediakan fasilitas perubahan, mengadakan evaluasi.

\section{Daftar Rujukan}

Arjanto, Paul. "Identifikasi Masalah Menggunakan Teknik ProblemCheckList Pada Mahasiswa Program Studi Bimbingan dan Konseling Universitas Pattimura”, Jurnal Konseling Indonesia, vol. 1, no. 1, 2015.

Gunarsa, Yulia Singgi D. Asas-Asas Psikologi Keluarga Idaman. Jakarta: Gunung Mulia. 2012.

Hidayat, Dede Rahmat. et al., Bimbingan Konseling Kesehatan Mental di Sekolah. Bandung: PT. Remaja Rosda Karya, 2013.

Kultsum, Ummu. "Pengaruh Implementasi Bimbingan dan Konseling terhadap Perilaku Delinkuen pada Peserta Didik", Auladuna, vol. 2, no. $1,2015$.

Novarita, Elsi. "Perilaku Bolos Siswa dan Implikasikasinya terhadap Layanan Bimbingan dan Konseling", Jurnal Konseling dan Pendidikan, vol. 2, no. 2, 2014.

Purwanto, Ngalim. Prinsip-Prinsip dan Teknik Evaluasi Pengajaran. Bandung: Remaja Rosdakarya, 2001.

Rakhmawati, Dini. "Konselor Sekolah Abad 21: Tantangan dan Peluang", Jurnal Konseling Gusjigang, vol. 3, no. 1, 2017.

Rozikan, Muhammad. "Spiritualitas Peran Konselor dalam Meningkatkan Kualitas Pelayanan Bimbingan Konseling”, Prosiding Seminar Bimbingan dan Konseling, vol. 1, no. 1, 2017. 